UDC 341.29+[372.76:340.131.5]

DOI https://doi.org/10.32849/2663-5313/2021.11.07

Oleh Ilnytskyi,

PhD in Law, Associate Professor, Senior Lecturer at the Department of Administrative and Finance Law, Ivan Franko National University of Lviv, 12, Sichovykh Striltsiv street, Lviv, Ukraine, postal code 79000, oleh.ilnytskyy@lnu.edu.ua

ORCID: orcid.org/0000-0001-7343-8810

Ilnytskyi, Oleh (2021). Citizens of Ukraine as subjects of special economic and other restrictive measures (sanctions) imposed by the Ukrainian state. Entrepreneurship, Economy and Law, 11, 54-62, doi https://doi.org/10.32849/2663-5313/2021.11.07

\title{
CITIZENS OF UKRAINE AS SUBJECTS OF SPECIAL ECONOMIC AND OTHER RESTRICTIVE MEASURES (SANCTIONS) IMPOSED BY THE UKRAINIAN STATE
}

Abstract. The purpose of the article is to establish legal grounds and feasibility of the imposition of special economic and other restrictive measures (sanctions) on citizens of Ukraine, as well as related guarantees of ensuring their rights, freedoms and interests.

Research methods. The contribution is developed on the basis of general scientific and special methods of scientific cognition.

Results. The author considered the validity of introducing special economic and other restrictive measures (sanctions) as the mechanism of state policy and requirements for ensuring the legitimacy of their imposition on citizens of Ukraine.

Conclusions. Special economic and other restrictive measures (sanctions) may be imposed on citizens of Ukraine only if they are entities conducting terrorist activities. That fact shall be confirmed by a court judgment adopted in the manner established by the Criminal Procedure Code of Ukraine or the Code of Administrative Proceeding of Ukraine. "Court authorization" is a generally recognized requirement to guarantee compliance with the rule of law in contentious legal relations. The procedure for administrative control through making a decision by the National Security and Defense Council of Ukraine, which the President of Ukraine puts into effect, as well as the right to the follow-up judicial control, cannot secure an alternative to the mentioned guarantees. Sanctions are measures of state coercion that are imposed on a person when implementing state policy through establishing additional conditions for economic and financial activities in Ukraine. Alternate and general formulation of sanctions in the National Security and Defense Council of Ukraine enforcement decision, which the President of Ukraine puts into effect, does not mean an illegal interference in rights, freedoms, and interests of persons who are subject to it; a sanction will be further realized in a particular context, ensuring the adjustment of the sanctions regime to an individual situation.

Key words: sovereignty, state coercion, judicial authorization, terrorist activity, restriction of rights, freedoms and interests.

\section{Introduction}

The current political and social situation of the armed aggression of the Russian Federation against Ukraine in the form of a "hybrid war" has led to real physical threats to sovereignty and national security. This requires adequate feedback from the state apparatus to meet and protect the state and its citizens, their rights and freedoms, from the relevant threats. The application of special economic and other restrictive measures (sanctions) following the Law of Ukraine "On Sanctions" dated August 14, 2014 № 1644-VII (hereinafter - the Law № 1644-VII) is an element of the new realityofthelegalregimeofpublicadministration.

The form of restrictive measures chosen by the Ukrainian statutory model widely defines a range of actors subjected to their imposition (para. 2 of Art. 1 and Art. 3 of the Law № 1644-VII). Given the essence of these measures, it inevitably raises the issue of the legitimacy of interference in the rights, freedoms, and interests of sanctions' addressees. The mechanism of sanctions is traditionally considered in the dimension of the evolution of reprisals in public international law. However, 
the last years of their application for combating the globalized challenges of international crime and terrorism changed the vector of their application from interstate sovereign relations to the state level - a person of private law.

The study of the current status of the application of sanctions in Ukraine shows the same approach - special economic and other restrictive measures are mainly regarded as operational ways to protect national interests, national security, sovereignty and territorial integrity of Ukraine, counter-terrorist activity and prevent violations, restore the violated rights, freedoms, and legitimate interests of citizens of Ukraine, society and the state against legal entities and individuals regardless of the extent of state sovereignty over them.

It should be noted that the rapid application of the relevant institution during 2018-2021 took place in the absence of comprehensive studies on the procedure for applying sanctions in its regulatory version. Instead, the study of the ontological nature of international legal sanctions has long been the subject of scientific and practical interest of leading international (O. Elagab, J. Crawford, K. Tomuschat) and domestic and Eastern European experts (V.A. Vasylenko, D.B. Levin, I.I. Lukashuk, Yu.V. Maniichuk, K.V. Manuilova, V.I. Menzhynskyi, S.V. Chernychenko, A.L. Cherniavskyi).

The consequence of using the mechanism of special economic and other restrictive measures (sanctions) is the emergence of a new category of disputes in case law appealing the decrees of the President of Ukraine, which implement the relevant measures. Thus, the lack of sufficient theoretical basis causes significant practical problems of an adequate settlement of the issue of synergies between public interests and compliance with the guarantees of the legal status of individuals in this mechanism, especially if it concerns their application to legal entities and individuals, who are residents of Ukraine, and the choice of extraordinary restrictive measures instead of ordinary coercive measures in public administration.

The purpose of this article is to establish the legal validity and justification of the imposition of special economic and other restrictive measures (sanctions) on citizens of Ukraine, as well as guarantees of ensuring related rights, freedoms and interests.

2. Institutionalization of special economic and other restrictive measures (sanctions) in the legislation of Ukraine

The wording of Art. 1 of the Constitution of Ukraine, which primarily characterizes Ukraine as a sovereign and independent state and its status as democratic, social and legal, indicates the consequent relations between the need to ensure sovereignty and independence within the State for further execution of its obligations to guarantee democracy, establish and protect human rights and freedoms as an element of law and order that secures the implementation of the constitutional principle of the social and rule-of-law state (para. 4 of the reasoning part of the Judgement of the Constitutional Court of Ukraine dated December 22, 2010 № 23-рп/2010). Therefore, para. 1 of Art. 17 of the Constitution of Ukraine stipulates that protecting the sovereignty and territorial integrity of Ukraine and ensuring its economic and information security shall be the most important function of the State and a matter of concern for all the Ukrainian people.

It is the Parliament in Ukraine that is entitled to represent the whole Ukrainian nation - the citizens of Ukraine of all nationalities - and act on their behalf, and thus, it is a representative body of state power (point 4, sub-para. 2.1, para. 2 of the reasoning part of the Opinion of the Constitutional Court of Ukraine (Grand Chamber) dated December 16, 2019 № 8-в/2019).

Despite the lack of direct reference in the Constitution of Ukraine to the mechanism of special economic and other restrictive measures (sanctions), the laws of Ukraine may also regulate other issues, the solution of which does not fall within the competence of other public authorities or local self-government bodies under the Constitution of Ukraine. This follows from para. 2 of Art. 85 of the Constitution of Ukraine.

Pursuant to point 17, para. 1 of Art. 92 of the Constitution of Ukraine, only laws of Ukraine shall determine the fundamentals of national security, the formation of the Armed Forces of Ukraine, and ensuring public order.

Special economic and other restrictive measures (sanctions) are "internally illegal" but justified by the purpose and grounds for their application, countermeasures" (Alland, 2002, pp. 1221-1222) and, at the same time, coercive measures as an element of the method of functioning of international law, one of the means of formally legal implementation of law (Lukashuk, 2005, p. 401). Consequently, they acquire the characteristics of universally recognized elements of the state and international policy focused on protecting national interests and ensuring the security of the individual, society and states from external and internal threats.

Acting upon the representative mandate and keeping in mind the preconditions 
specified in the Preamble of Law № 1644-VII, the Verkhovna Rada of Ukraine statutorily set the legal regime of applying special economic and other restrictive measures (sanctions) in Ukraine and thus legalized them as an instrument of public policy.

The procedure, established by the Law

№ 1644-VII, for applying special economic and other restrictive measures (sanctions) prescribed by the decision of the National Security and Defense Council of Ukraine (hereinafter - NSDC), which the decree of the President of Ukraine puts into effect, also corresponds to the constitutional tasks and powers of the NSDC and the President of Ukraine; the latter ensures the independence, national security, and legal succession of the State (para. 1 of Art. 106 of the Constitution of Ukraine)

The Constitutional Court of Ukraine holds that the provisions of the Constitution of Ukraine, which outline the scope and essence of the powers of the President of Ukraine and the Verkhovna Rada of Ukraine, can be specified only at the level of Ukrainian laws. However, that kind of specification cannot lead to distortion of the provisions of the Constitution of Ukraine or go beyond it (point 5, sub-para. 2.2, para. 2 of the reasoning part of the Decision of the Constitutional Court of Ukraine (Grand Chamber) dated September 16, 2020 № 11-p/2020).

At the same time, in point 6, sub-para. 2.1, para. 2 of the reasoning part of the Decision of the Constitutional Court of Ukraine of February 25, 2009 № 5-рп/2009, the body of constitutional jurisdiction concluded that the systematic analysis of the Constitution of Ukraine gives grounds to believe that the Verkhovna Rada of Ukraine, the President of Ukraine, and the Cabinet of Ministers Ukraine have individual constitutional powers in the area of national security and defense, and only the President of Ukraine has the constitutional authority to exercise leadership in the mentioned areas. It means that the President of Ukraine guides the activity of subjects of national security and defense of the state while exercising such leadership.

Thus, the decrees of the President of Ukraine, which put in effect the NSDC decisions on the application of special economic and other restrictive measures (sanctions) adopted within the powers provided by the Constitution of Ukraine and in the form of competence exercise, which is enshrined in para. 3 of Art. 106 of the Constitution of Ukraine, are binding on all entities under the jurisdiction of Ukraine.
3. Legal nature of special economic and other restrictive measures (sanctions) in the legislation of Ukraine and their clearness

The legal basis of special economic or other restrictivemeasures(sanctions)applied by thestates against threats to sovereignty and a constitutional order relies on Art. 41 of the UN Charter: "The Security Council may decide what measures not involving the use of armed force are to be employed to give effect to its decisions, and it may call upon the Members of the United Nations to apply such measures. These may include complete or partial interruption of economic relations and of rail, sea, air, postal, telegraphic, radio, and other means of communication, and the severance of diplomatic relations".

The theory of international law interprets economic sanctions as a measure of lawful coercion (Tomushat, 1994; Lukashuk, 2005) or through the prism of legitimate countermeasures (Cherniavsyi, 2017). However, according to the standards of international law, such coercion is the outcome of an illegal act, the nature of which should be grounded on international law, not the national law of the state; the application of such measures should not create conditions for violating fundamental tenets of international law or human rights and freedoms; the sole purpose of sanctions is to restore the victim's legitimate rights and interests and restore the status quo ante, including compensation for pecuniary damage (Crouford, 1999, pp. 436-439). Thus, the vector of their action is always directed outwards and must compensate for the limited influence of the state on the violator that is not under its internal sovereign jurisdiction.

A systems study of the provisions of the Law № 1644-VII allows one to assert that special economic and other restrictive measures (sanctions) are law-enforcement in their nature, have a restrictive coercive effect on the violator. However, compared to the measures of ordinary legal responsibility, which has the punishment for the act as its primary purpose, listed in Art. 4 of the Law № 1644-VII, special economic and other restrictive measures (sanctions) are ones designed to prevent and put an end to threats, in response to which they are applied in the decisions or actions of subjects.

The personal and sectoral sanctions listed in the Law № 1644-VII, in their effects, are temporary measures of operational influence on the conduct of participants by imposing special restrictions under the framework of public policy in some areas (economic, financial, infrastructure, diplomatic, environmental, trade, cultural, etc.). They are intended to point out the violation, eliminate opportunities for keeping illegal activities and causing major 
damage to protected legal relations before remedying the situation, avoid potential use of resources and capabilities through the state mechanism to harm its protected fundamental values. There is no doubt that they are adversarial to the rights and interests of addressees that highlights their essence.

With the application of special economic and other restrictive measures (sanctions) to persons under private law, the issue of assessing the legality of the intervention arises in each case. Moreover, given the nature of sanctions, it is necessary to refer to the similar practice of the Constitutional Court of Ukraine. The Court holds that one should distinguish the concept of "restriction of fundamental rights and freedoms" from the concept of "fixation of the limits of the essence of rights and freedoms" adopted in lawmaking through applying legal methods (techniques) recognizing such practice admissible if additional standardization of the right's enjoyment by the special legislation aims not to narrow the scope of rights and freedoms but to specify the content and regulation of procedural issues and outline the general limits of the fundamental rights (point 2, para. 10 of the reasoning part of the Decision of the Constitutional Court of Ukraine dated June 12, 2007 № 2-pп/2007).

In this aspect, a good part of special restrictive measures applied to a particular person (personal sanctions) is characterized by the establishment of additional conditions for economic and financial activities in Ukraine, the use of state resources owned by the Ukrainian people to prevent their use to the detriment of the people, state or universally recognized values of the world law and order. They do not restrict the rights completely as measures of responsibility. However, the state, represented by authorized bodies, has changed approaches to the procedure for exercising rights, freedoms, and interests of an individual to ensure the public interest, which is manifested in the statutory purpose of sanctions.

Alternate and general wording of sanctions in the regulatory prescriptions of Art. 4 of the Law № 1644-VII, as well as their wordfor-word reproduction in a law enforcement decision, does not indicate unlawful interference with the rights, freedoms, and interests of persons subject to its application because such a sanction will be further implemented under specific conditions of disputed legal relations (for example, on the ratio of the validity term of sanctions and the validity term of a specific suspended license) to adjust the sanctions regime to the individual situation of the person.

If the imposition of specific special economic or other restrictive measures results in the restriction of certain rights, freedoms and interests of the individual, it should be noted that threats to national interests, national security, sovereignty, and territorial integrity of the state, terrorist activity are a universal statutory criterion for the lawful application of the restrictions with regard to the provisions of the Constitution of Ukraine, acts of international law on the protection of human rights and freedoms, the practice of human rights jurisdiction in Europe and the world to the extent of derogation from international obligations in this area required by the severity of the situation and granted that such measures do not conflict with its other obligations under international law (Art. 15 of the Convention for the Protection of Human Rights and Fundamental Freedoms). The Resolution of the Verkhovna Rada of Ukraine dated May 21, 2015 № 462-VIII approved the Statement of the Verkhovna Rada of Ukraine "On the Derogation of Ukraine from certain Obligations under the International Covenant on Civil and Political Rights and the Convention for the Protection of Human Rights and Fundamental Freedoms".

The essential content of the application of sanctions in the legislation of Ukraine deserves special attention; some of them are detailed by the Resolution of the Board of the National Bank of Ukraine dated October 1, 2015 № 654 "On Ensuring the Implementation and Monitoring of the Effectiveness of Personal Special Economic and Other Restrictive Measures (Sanctions)". The study of this act allows predicting order and consequences of the sanctions' application in the financial sector which concurrently regulates the operation of the state apparatus and eliminates objections about the vagueness and uncertainty of regulation.

4. Guarantees of the lawful imposition of special economic and other restrictive measures (sanctions) on citizens of Ukraine

The introduction of the mechanism of personal (targeted) sanctions in international practice has arisen the issue of ensuring respect for the rights of individuals subjected to sanctions. As a general rule, it is agreed that the rights restricted by sanctions are not absolute, and public interests justify such interferences (as discussed in previous sections of the article). Therefore, a more important task for the entity imposing sanctions is to ensure compliance with the procedure for applying sanctions. The procedure includes: a proper notification stating the reasons for the application of sanctions; ample evidence to justify sanctions; hearing; an option of reviewing the decision on the application of sanctions by an independent court (Chachko, 2019, p. 157). 
Following the case law of the European Court of Human Rights, the assessment of the expediency of interference with guaranteed human rights and freedoms is based on the study of whether it is conducted under the law, whether it meets the legitimate aim, and whether it is necessary for a democratic society. (sub-paras. 42-46 of the Judgments in the case "Klass and Others v. Germany" dated September 6, 1978).

The legitimate restriction of constitutional rights and freedoms of man and citizen should be understood as the possibility of state intervention set by the Constitution of Ukraine, which meets the rule of law, necessity, expediency and proportionality in a democratic society, in the scope of constitutional rights and freedoms of man and citizen using legal remedies. The restriction's purpose is to protect fundamental values in society, which include inter alia life, human freedom and dignity, public health and morality, national security, public order (point 2, para. 6 of the reasoning part of the Decision of the Constitutional Court of Ukraine dated July 12, 2019 № 5-p(I)/2019).

The expression "under the law" in terms of setting restrictions on human rights and freedoms to combat terrorism requires, first, that the disputed measure has relevant grounds in national law; it also concerns the quality of the law in question, requiring that it be consistent with the rule of law and be available to the mentioned persons, who must also be able to foresee its consequences (see, inter alia, Kruslin v. France, 24 April 1990, § 27, Series A № 176-A; Huvig, cited above, § 26; Lambert v. France, 24 August 1998, § 23, Reports 1998 V; Perry v. the United Kingdom, № 63737/00, $\S$ 45, ECHR 2003 IX (extracts), Dumitru Popescu v. Romania (№ 2), № 71525/01, $\S 61,26$ April 2007, Association for European Integration, cited above, $\S 71$, and Liberty, cited above, § 59).

In the issues affecting fundamental rights, the expression of the executive's discretion in the field of national security in terms of unlimited power will contradict the rule of law, one of the fundamental principles of a democratic society enshrined in the Convention. Therefore, the law shall specify the scope of any such discretion given to the competent authorities and the way of its implementation with sufficient clarity, keeping in mind the legitimate aim of the relevant preventive measure, to provide the person with adequate protection against arbitrary interference (see Roman Zakharov, cited above, § 247) (sub-paras. 59, 62, 65 of the Judgment in the case "Szabó and Vissy v. Hungary" dated January 12, 2016 (application № 37138/14)).
Assessing the level of legitimacy of interference with rights and freedoms of an individual in the context of judicial evaluation of compliance with their guarantees, since the $80 \mathrm{~s}$ of the twentieth century, the European Court of Human Rights has pointed out that one of the significant factors subjected to consideration is the level reached in recent years by terrorism in Europe as a threat, countering which requires the application of restrictive measures. Democratic societies face the threat of highly sophisticated forms of espionage and terrorism. Consequently, in order to counter such threats effectively, the state must be able to take extraordinary countermeasures against subversives. The Court notes that in determining the conditions which activate a system of the relevant measures, the state legislative branch exercises the discretionary right (cf., mutatis mutandis, Judgment in the case of De Wilde, Ooms and Versyp v. Belgium dated June 18, 1971, Series A, № 12, pp. 45-46, § 93; and in the case of Golder dated February 21, 1975, Series A, $\S 18$, pp. 21-22, § 45; cf., in relation to Article 10 $\S 2$, Judgment in the case of Engel and Others dated June 8, 1976, Series A № 22, pp. 41-42, $\S 100$, and in the case of Handyside dated December 7, 1976, Series A, № 24, p. 22, § 48).

At the same time, the Court emphasizes this does not mean that the State is granted unlimited discretion to take extraordinary measures. The assessment of their legitimacy is relative: it depends on all circumstances of the case, i. e., nature, scale, and duration of potential measures, the grounds necessary to issue an order to apply the measures; it depends on the authorities empowered to authorize, implement and control such measures and on the legal remedy prescribed by the national law (paras. 48-50 of the Judgment in the case "Klass and Others v. Germany" dated September 6, 1978).

In this context, a well-defined determination of the subjective feature of the application of state coercive measures is one of the priority tasks.

Examining the range of addressees subjected to personal special restrictive measures (sanctions), one draws attention to the fact that under the system application of the provisions of para. 2 of Art. 1, para.1 of Art. 3, para. 3 of Art. 5 of the Law № 1644-VII, this international law institute is implemented in the current legislation of Ukraine in terms of its application, firstly, to a foreign legal entity, a legal entity under the control of a foreign legal entity or non-resident individual, foreigners, stateless persons (it follows generally accepted principles of international law) and, secondly, 
to entities conducting terrorist activities without imposing any restrictions based on nationality or residence of such persons. Thus, a legal entity-resident of Ukraine and a natural person-citizen of Ukraine may be subjected to special economic and other restrictive measures (sanctions) under the Law № 1644-VII only in terms of recognizing them as terrorist entities.

If no one has the right to challenge the state's discretion to protect its sovereignty by applying such an extraordinary mechanism as sanctions, then the resolution of the issue of waiving sanctions in the national legal system in favor of international coercion is one of the aspects of assessing the legitimacy of restrictions of rights, freedoms, and interests through special restrictive measures; especially if the substantial and procedural level of guarantees in the latter case is significantly lower for the legal status of the person. At the same time, it is obvious that this cannot be justified by the recommendations on establishing international cooperation and supporting the actions of the world community in combating the global phenomenon (Barash, 2017) because both the source of decisions and the addressee of the consequences are within single sovereignty.

In the context of the above stipulations about ensuring legal certainty and hence limiting the discretion of law enforcement, imperative prescriptions do not allow specifying the addressees of sanctions in an expanded interpretation of the regulatory prescription. The specification of an addressee is inextricably linked with the normative content of the understanding of the concept of "terrorism" and "terrorist activity" (item 2, Art. 1 of the Law of Ukraine "On Combating Terrorism” dated March 20, 2003 № 638-IV (hereinafter - the Law № 638IV)) and the legislative definition of "national security", "national interests" and threats to national security of Ukraine formulated under the Law (sub-paras. 6, 9, 10, para. 1, Art. 1 of the Law of Ukraine "On National Security of Ukraine” dated June 21, 2018 № 2469-VIII (hereinafter - the Law № 2469-VIII)), which are affected by terrorism.

Assessing the elucidation of these features in applying to an individual, the European Court of Human Rights recalls that even in the field of covert surveillance, where predictability is of particular concern, the concepts of the danger of terrorist acts and the need for rescue operations are clear enough to comply with the law. For the Court, the requirement of "predictability" of the law does cross a line to compel States to enact legislation that specifies all potential situations that may entail a decision to initiate a covert surveillance operation. In fact, the mention of a terrorist threat or rescue operation can be regarded as providing citizens with the necessary indication (compare and contrast Iordachi and Others, cited above, § 46). At the same time, for the Court, nothing in the text of the relevant legislation indicates that the concept of "terrorist acts" used in section $7 / \mathrm{E}$ (1) a) (ad) of the Police Act does not coincide with the similarly defined crime, which is found the Criminal Code. (see para. 16 above) (para. 65 of the Judgment in the case "Szabó and Vissy v. Hungary" dated January 12, 2016 (application № 37138/14)).

The Criminal Code of Ukraine in Arts. 258-258-5, as in the cited case of Hungary, criminalizes the manifestations of terrorist activity, which determines the need to ensure standards of protection of a citizen of Ukraine from a criminal charge in resolving the justification of imposing special restrictive measures against him/her as a terrorist based on the presumption of innocence under para. 1 of Art. 62 of the Constitution of Ukraine.

Thus, terrorism and terrorist activity are legal categories, not political ones. Accordingly, they should be assessed by relying only on the mentioned feature (outside of political activity), evidence, or intelligence information about terrorist activities and meet the "reasonable suspicion" standard (Judgment in the case "O'Hara v. the United Kingdom” dated October 16, 2001, application № 37555/97).

In addition to criminal law qualification, a person's involvement in terrorist activities in Ukraine may be confirmed by a court in administrative proceedings (Art. 284 of the Code of Administrative Proceedings of Ukraine) at the request of the Security Service of Ukraine pursuant to Art. 11-1 of the Law № 638-IV for inclusion/exclusion in/from the relevant sanctions lists, including the list of persons connected with terrorist activities or in respect of whom international sanctions have been applied.

Preliminary availability of a court decision about the establishment of the fact of a person's involvement in terrorism or the grounds for inclusion in the relevant list (so-called "judicial authorization") is a sufficient guarantee of the national system of protection of individual rights in case of their further restrictions in applying special restrictive measure based on the decisions; in terms of the application of sanctions, it reduces the NSDC decision to the selection of those measures, according to Art. 4 of the Law № 1644-VII, which meet the requirements of ensuring the purpose of their application to the person. 
However, if the NSDC of Ukraine, by its decision to apply special economic and other restrictive measures (sanctions), pre-qualifies the actions of a person as one involved in terrorist activities, the NSDC of Ukraine, together with the President of Ukraine, acts as "the court" in disputable legal relations to assess the guarantees of human rights (see, e. g., sub-paras. 87-91 of the Judgment in the case of "Oleksandr Volkov v. Ukraine" dated January 9, 2013, application № 21722/11).

The distribution of powers between the political executive and the judiciary has become increasingly important in its practice (see the Judgment in the case of Stafford v. the United Kingdom (proceeding in execution), application № 46295/99, § 78, ECHR 2002-IV). At the same time, neither Article 6 nor any other provision of the Convention requires States to adhere to any theoretical constitutional concepts regarding the permissible limits of interaction between the branches of government (see the Judgment in the case of Kleyn and Others v. the Netherlands (proceeding in execution), applications № 39343/98, № 39651/98, № 43147/98 and № 46664/99, § 193, ECHR 2003-VI).

Instead, the activity of the National Security and Defense Council of Ukraine apparently does not correspond to the characteristics of a "fair and impartial court" as defined in para. 1 of Art. 6 of the Convention, as it is a body under the President of Ukraine that coordinates and controls the activity of executive power bodies in the area of national security and defence; the President of Ukraine forms the personal membership of the National Security and Defense Council of Ukraine (Art. 107 of the Constitution of Ukraine). Thus, the NSDC, depending on the President of Ukraine as the head of state, helps him implement the principles of domestic and foreign policy on national security and defense and coordinates executive bodies' relevant activities in peacetime (incl., the Security Service of Ukraine, the data of which contribute to the decision on the application of sanctions). Therefore, it has neither functional nor institutional independence and impartiality to settle the issue of addressing sanctions; it is directly interested in taking measures to improve prevention and combating threats to national interests and national security in terms of its competence and functions in the state apparatus.

A lack of preliminary judicial authorization to interfere in the rights, freedoms, and interests of individuals due to the application of extraordinary measures to combat global threats is a particular problem
(Judgment in the case "Szabó and Vissy v. Hungary" dated January 12, 2016, application № 37138/14, pp. 73-78). Other forms of control by law enforcement agencies and officials, which are elements of the law enforcement system and have wide powers to apply countermeasures in the fight against terrorism, are mainly political - they are incompetent in providing the adequate assessment of urgency about the objectives and means considered. Although the Court agrees with the functional arguments that such individuals and bodies are better adapted to authorization than judges, it is not convinced of this when it comes to analyzing objectives and means in terms of urgency.

As for a body empowered to authorize restrictive measures, a non-judicial body may comply with the Convention (see, for example, Klass and Others, cited above, $\S 51$; Weber and Saravia, cited above, § 115; and Kennedy, cited above, $\S 31$ ), if this body is sufficiently independent of the executive branch (see Roman Zakharov, cited above, $\S$ 258). However, the political nature of authorization and control increases the risk of abuse. The Court recalls that the rule of law means, inter alia, that the interference of executive bodies in human rights shall be subject to effective control, which must be enshrined by litigation. If there is no other way, judicial control at least provides the best guarantees of independence, impartiality and proper procedure. In a realm where abuse seems potentially easy to commit in individual cases and where it can have serious consequences for a democratic society, it is advisable to entrust a judge with supervision (see Klass and Others, cited above, $\S 55$ and $\$ 56)$. The Court recalls that in the case of Dumitru Popescu (cited above, §§ 70-73), it has expressed an opinion that either a body granting the interception authorization should be independent, or there should be control over the authorizing body by a judge or an independent agency. Accordingly, in this context, control of an independent body usually a judge with specific experience, should be the rule, and reserve methods should be the exception, ensuring close supervision (see Klass and Others, cited above, $\S 42$ and $\S 55$ ). The ex-ante authorization of such a measure is not an absolute requirement per se, as this may balance shortcomings of authorization in the part which has thorough post factum juridical supervision (see Kennedy, cited above, $\S 167$ ). From the Court's perspective, the control of a politically responsible member of the executive branch does not provide adequate guarantees. 
Post factum judicial control, by granting the right to appeal against the court decisions, actions, or omissions of public authorities, officials, and officers in the field of national security and defense (Art. 9 of the Law № 2469 VIII), is not an efficient alternative, given that even the invalidation of the relevant decision of the NSDC of Ukraine on the application of special restrictive measures and its abolition does not restore rights, freedoms or interests limited during the restrictions.

Moreover, such control is currently carried out only when a person brings the matter before the court when appealing the relevant decisions. In fact, it causes the transfer of responsibility for proving the legality/illegality of coercive measures from the power entity to the person.

\section{Conclusions}

Special economic and other restrictive measures (sanctions) may be applied to citizens of Ukraine only if they are entities involved in terrorist activities. This fact must be confirmed by a court decision adopted following the procedure established by the Criminal Procedure Code of Ukraine or the Code of Administrative Procedure of Ukraine.

As the application of coercive measures to citizens of Ukraine and legal entities-residents in Ukraine relies on the recognition of their involvement in criminal activities, judicial authorization during the application of such restrictive measures is a universally recognized requirement to ensure compliance with the rule of law in disputes. The administrative procedure of control through the decision of the NSDC of Ukraine, which is put in force by the decree of the President of Ukraine, as well as the right to follow-up judicial control of its legality, cannot provide an alternative to the above guarantees.

Sanctions are the measures of state coercion applied to a person while implementing state policy by establishing additional conditions for economic and financial activities in Ukraine, using state resources owned by the Ukrainian people to prevent their exploitation to the detriment of the people, state or universally recognized values of the world law and order. Not all of them are means restricting rights, but the state, represented by authorized bodies, is changing approaches to exercising individual rights to ensure the relevant public interest, which is manifested in the statutory purpose of sanctions. Sanctions are not measures of the legal responsibility of an individual.

Pursuant to Art. 4 of the Law № 1644-VII, alternate and general wording of sanctions by reproducing them in the law enforcement decision of the NSDC, which is put into effect by the decree of the President of Ukraine, does not indicate unlawful interference with the rights, freedoms and interests of persons subjected to their application; such a sanction is further implemented under specific conditions of the disputed legal relations, ensuring the adaptation of the sanctions regime to a particular situation of a person.

\section{References:}

Alland, D. (2002). Contrmeasures of General Interest. European Journal of International Law, vol. 13, no. 5, pp. 1221-1239 (in English).

Barash, Ye. (2017). Suchasni rysyky skoiennia terorystychnyh aktiv: analis ta pravova harakterystyka [Modern risk of committing terrorist akts: analysis and legal characteristics]. Visnyk Nazionalnoyi Academiyi Pravovyh Nauk Ukrainy, no. 3(90), pp. 150-158 (in Ukrainian).

Chachko, E. (2019). Due Process Is in the Details: U.S. Targeted Economic Sanctions and International Human Rights Law. The American Society of International Law, vol. 113, no. 25, pp. 157-162. DOI: 10.1017/aju.2019.25 (in English).

Cherniavskiy, A.L. (2017). Pryntsypy ta umovy zastosuvannia kontrsahodiv u suchasnomu mizhnarodnomu pravi [Principles and conditions of application of countermeasures in the contemporary international law]. Problemy zakonnosti, issue 139, pp. 278-285. DOI: 10.21564/2414-990x.139.114563 (in Ukrainian).

Crawford, J. (1999). Revising the Draft Articles on State Responsibility. European Journal of International Law, vol. 10, no 2, pp. 435-460 (in English).

Lukashuk, I.I. (2004). Pravo mezhdunarodnoj otvetstvennosti [The law of international responsibility]. Moscow: Wolters Kluwer (in Russian).

Tomuschat, C. (1994). Are Counter-measures Subject to Prior Recourse to Dispute Settlement Procedures? European Journal of International Law, vol. 5, no. 1, pp. 77-87 (in English). 


\section{Олег Ільницький,}

кандидат юридичних наук, доцент, доцент кафедри адміністративного та фінансового права, Львівський національний університет імені Івана Франка, вулиця Січових Стрільиів, 12, Львів, Україна, індекс 79000, oleh.ilnytskyy@lnu.edu.иа

ORCID: orcid.org/0000-0001-7343-8810

\section{ГРОМАДЯНИ УКРАЇНИ ЯК СУБ'ЄКТИ ЗАСТОСУВАННЯ СПЕЦІАЛЬНИХ ЕКОНОМІЧНИХ ТА ІНШИХ ОБМЕЖУВАЛЬНИХ ЗАХОДІВ (САНКЦІЙ) ІЗ БОКУ УКРАЇНСЬКОЇ ДЕРЖАВИ}

Анотація. Мета статmi - встановити правові підстави та обгрунтувати доцільність застосування спеціальних економічних та інших обмежувальних заходів (санкцій) до громадян України, а також пов'язані із цим гарантії забезпечення їхніх прав, свобод та інтересів.

Методи дослідження. Роботу виконано на підставі загальнонаукових та спеціальних методів наукового пізнання.

Результати. Розглянуто питання конституційності запровадження спеціальних економічних та інших обмежувальних заходів (санкцій) як механізму державної політики, а також вимоги щодо забезпечення правомірності їх застосування до громадян України.

Висновки. Спеціальні економічні та інші обмежувальні заходи (санкції) можуть застосовуватися до громадян України лише в тому разі, якщо вони є суб'єктами, які здійснюють терористичну діяльність. Це має бути підтверджене судовим рішенням, прийнятим у порядку, встановленому Кримінальним процесуальним кодексом України або Кодексом адміністративного судочинства України. «Судова авторизація» є загальновизнаною вимогою гарантування дотримання принципу верховенства права у спірних правовідносинах. Адміністративний порядок контролю шляхом прийняття рішення Ради національної безпеки і оборони України, яке вводиться в дію указом Президента України, а також право на подальший судовий контроль не здатні забезпечити альтернативу зазначених гарантій. Санкції є заходами державного примусу, які застосовуються до особи у процесі здійснення державної політики шляхом встановлення додаткових умов режиму економічної та фінансової діяльності на території України. Санкції не є заходами юридичної відповідальності особи. Альтернативне та загальне формулювання санкцій у правозастосовному рішенні Ради національної безпеки і оборони України, яке вводиться в дію указом Президента України, не свідчить саме по собі про протиправне втручання у сферу прав, свобод та інтересів осіб, до яких воно застосоване, оскільки надалі така санкція підлягатиме реалізації відповідно до конкретних умов із забезпеченням адаптації режиму санкцій до індивідуальної ситуації.

Ключові слова: суверенітет, державний примус, судова авторизація, терористична діяльність, обмеження прав, свобод та інтересів.

The article was submitted 13.11.2021

The article was revised 06.12.2021

The article was accepted 27.12.2021 